\title{
Risiko Bisnis, Profitabilitas, dan Struktur Aktiva Sebagai Penentu Struktur Modal Perusahaan Makanan dan Minuman
}

\author{
Ni Wayan Meitriyani ${ }^{1}$ \\ Fakultas Ekonomi dan Bisnis \\ Universitas Udayana, Indonesia
}

\author{
Ni Gusti Putu Wirawati2 \\ Fakultas Ekonomi dan Bisnis \\ Universitas Udayana, Indonesia
}

\begin{abstract}
Surel: meitriyanii@gmail.com
ABSTRAK

Tujuan penelitian untuk mengetahui pengaruh risiko bisnis, profitabilitas, dan struktur aktiva terhadap struktur modal. Penelitian ini mengambil sampel pada perusahaan manufaktur yang terdaftar di Bursa Efek Indonesia periode 2015-2019. Sampel yang digunakan adalah purposive sampling. Teknik analisis yang digunakan regresi linear berganda. Hasil penelitian risiko bisnis berpengaruh positif signifikan terhadap struktur modal pada Perusahaan Makanan Dan Minuman Yang Terdaftar di BEI Tahun 2015-2019 sedangkan Profiabilitas berpengaruh negatif signifikan terhadap struktur modal pada Perusahaan Makanan Dan Minuman Yang Terdaftar di BEI, serta struktur aktiva berpengaruh positif signifikan terhadap struktur modal pada Perusahaan Makanan Dan Minuman Yang Terdaftar di BEI Tahun 2015-2019.
\end{abstract}

Kata Kunci: Food And Beverage; Risiko Bisnis; Profiabilitas; Struktur Aktiva.

\section{Business Risk, Profitability, and Asset Structure as Determinants of the Capital Structure of Food and Beverage Companies in BEI}

\begin{abstract}
The purpose of this study was to determine the effect of business risk, profitability, and asset structure on capital structure. This study takes samples from manufacturing companies listed on the Indonesia Stock Exchange for the 2015-2019 period. The sample used is purposive sampling. The analysis technique used is multiple linear regression. The results of business risk research have a significant positive effect on the capital structure of Food and Beverage Companies Listed on the IDX in 2015-2019 while profitability has a significant negative effect on the capital structure of Food and Beverage Companies Listed on the IDX, and asset structure has a significant positive effect on the capital structure in Food and Beverage Companies Listed on the Indonesia Stock Exchange in 2015-2019.
\end{abstract}

Keywords: $\quad$ Food and Beverage; Business Risk; Profitability; Asset Structure.

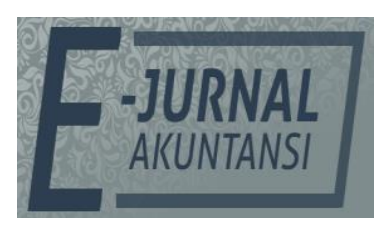

e-ISSN 2302-8556

Vol. 31 No. 11

Denpasar, November 2021

Hal. 2748-2760

10,24843/EJA.2021.v31.i11.p06

PENGUTIPAN:

Meitriyani, N. W., \& Wirawati,

N. G. P. (2021). Risiko Bisnis,

Profitabilitas, dan Struktur Aktiva Sebagai Penentu

Struktur Modal Perusahaan Makanan dan Minuman.

E-Jurnal Akuntansi,

31(11), 2748-2760

RIWAYAT ARTIKEL:

Artikel Masuk: 16 Februari 2021

Artikel Diterima:

27 November 2021

Artikel dapat diakses: https:/ / ojs.unud.ac.id/index.php/Akuntansi/index 


\section{PENDAHULUAN}

Struktur modal yang kuat merupakan salah satu faktor yang membuat suatu perusahaan memiliki daya saing dalam jangka panjang. Sehingga keputusan dalam penggunaan sumber-sumber dana yang dipakai untuk memperkuat struktur modal suatu perusahaan tidak dapat dilihat sebagai keputusan yang sederhana tetapi keputusan yang memiliki implikasi kuat terhadap apa yang akan terjadi di masa mendatang (Fahmi, 2016).Berkaitan dengan hal tersebut keputusan pencarian sumber pendanaan dalam rangka memperkuat struktur modal menjadi keputusan penting yang harus dikaji lebih mendalam. Menurut Fahmi (2016). menyatakan bahwa struktur modal merupakan gambaran dari bentuk proporsi finansial perusahaan antara modal perusahaan yang bersumber dari utang jangka panjang dan modal perusahaan yang bersumber dari setoran sendiri yang digunakan sebagai pembiayaan suatu perusahaan.

Rodoni \& Ali (2014)menjelaskan struktur modal merupakan proporsi untuk menentukan pemenuhan kebutuhan belanja perusahaan, apakah dengan penggunaan hutang, ekuitas, atau dengan menerbitkan saham. Struktur modal harus dipertimbangkan dengan baik, sehingga sumber pendanaan yang dipilih adalah alternatif terbaik bagi perusahaan. Pengambilan keputusan yang salah mengenai struktur modal dapat berdampak pada posisi

Dalam penelitian ini tidak semua faktor yang mempengaruhi struktur modal perusahaan akan dibahas. Hanya beberapa faktor yang akan dibahas pada penelitian ini yaitu risiko bisnis, profitabilitas dan struktur aktiva. Menurut Gitman (2009) dalam Arabella (2018) Risiko bisnis yakni risiko dari perusahaan saat tidak dapat menutupi biaya operasional dan dipengaruhi oleh stabilitas pendapatan dan biaya. Hasil temuan Bhawa \& Dewi (2015), risiko bisnis berpengaruh negatif tidak signifikan terhadap struktur modal perusahaan property dan real estate yang terdaftar di Bursa Efek Indonesia periode 2010-2014. Penelitian yang dilakukan oleh Primantara \& Dewi (2016) juga menyatakan bahwa risiko bisnis berpengaruh negatif signifikan terhadap struktur modal dengan menggunakan perusahaan rokok yang terdaftar di Bursa Efek Indonesia periode 2010-2014.

Peckingorder theory mengungkapkan bahwa perusahaan yang memiliki tingkat profitabilitas yang tinggi cenderung untuk menggunakan sumber dana internal berupa laba ditahan kemudian menggunakan pendanaan eksternal yang relatif rendah. Khairin \& Harto (2014) menyatakan bahwa profitabilitas berpengaruh positif signifikan terhadap struktur modal. Hasil penelitian ini didukung dengan hasil penelitian yang dilakukan oleh Setyawan et al., (2016) menunjukkan bahwa profitabilitas berpengaruh memiliki pengaruh positif dan signifikan terhadap struktur modal. Namun temuan berbeda diungkap oleh Pattweekkongka \& Napompech (2014), Juliantika \& Dewi (2016), Ananto (2015), yang menemukan hasil bahwa profitabilitas memiliki pengaruh negatif signifikan terhadap struktur modal perusahaan.

Struktur aktiva menunjukkan perbandingan aktiva lancar dengan aktiva tetap (Riyanto, 2011). Aktiva tetap yang dimiliki oleh perusahaan akan digunakan dalam menjalankan kegiatan operasional perusahaan. Perusahaan yang memiliki jumlah aktiva lancar yang lebih besar akan memprioritaskanpenggunaan hutang jangka pendek. Jadi, semakin tinggi struktur aktiva maka struktur modal 
perusahaan juga akan semakin tinggi. Struktur aktiva memiliki pengaruh negatif signifikan terhadap struktur modal.

Liestyasih \& Yadnya (2015) menemukan bahwa struktur aktiva memiliki pengaruh negatif signifikan terhadap struktur modal. Hasil penelitian tersebut juga didukung oleh temuan Sheikh \& Wang (2011), Alipour et al., (2015), Khairin \& Harto (2014) yang mengemukakan bahwa struktur aktiva memiliki pengaruh negatif signifikan terhadap struktur modal perusahaan. Beberapa penelitian lainnya menunjukkan hasil yang tidak konsisten atau berbeda. Seperti yang dikemukakan oleh Suweta \& Dewi (2016), Pattweekkongka \& Napompech (2014), Liem et al., (2013) yang menemukan bahwa struktur aktiva memiliki pengaruh positif signifikan terhadap struktur modal.

Penelitian ini dilaksanakan pada perusahaan manufaktur sub sektor Makanan dan Minuman di Bursa Efek Indonesia. Perkembangan sektor makanan dan minuman (Food And Beverage) selalu mengalami peningkatan sepanjang tahun. Perusahaan makanan dan minuman memiliki tingkat persaingan yang tinggi, sehingga diperlukannya kinerja perusahaan yang selalu prima agar unggul dalam persaingan. Kondisi kinerja perusahaan yang selalu prima turut memengaruhi ketertarikan investor terhadap perusahaan tersebut.

Teori keagenan atau teori agensi pertama kali dikemukakan oleh Michael C. Jensen dan William H. Meckling pada tahun 1976. Jensen \& Meckling (1976) menyatakan bahwa teori keagenan merupakan teori yang mendeskripsikan pemegang saham sebagai prinsipal dan manajemen sebagai agen. Teori keagenan merupakan teori yang berlandaskan pada hubungan antara prinsipal dan agen yang berfokus pada penentuan kontrak yang paling efisien untuk agen dan prinsipal. Konflik keagenan ini akan semakin meningkat dengan adanya asimetri informasi yang dimiliki oleh prinsipal dan agen. Seorang manajer memiliki lebih banyak informasi yang relevan baik mengenai kemampuan dirinya maupun kapasitas perusahaan secara keseluruhan sementara pemegang saham tidak memiliki informasi yang cukup mengenai kinerja manajer untuk meningkatkan profitabilitas perusahaan.

Teori sinyal pertama kali dikemukakan oleh Michael Spence (1973) dalam penelitiannya yang berjudul Job Market Signaling. Sinyal akan menandakan adanya isyarat yang dilakukan oleh pihak manajemen perusahaan kepada pihak luar atau investor. Menurut Brigham \& Houston (2011:184), teori sinyal berkaitan dengan perilaku manajemen perusahaan dalam memberi petunjuk atau sinyal kepada investor mengenai pandangan manajemen pada prospek perusahaan di masa mendatang. Dorongan memberikan sinyal muncul dikarenakan adanya asimetri informasi antara manajemen perusahaan dengan para investor. Jika terjadi penurunan pembayaran dividen akan dianggap sebagai sinyal negatifyang berarti perusahaan mempunyai prospek yang tidak begitu baik sehingga permintaan pasar terhadap saham perusahaan tersebut akan menurun (Ariandani \& Yadnyana, 2016).

Ketidakmampuan suatu perusahaan dalam memenuhi kebutuhan dananya untuk kegiatan operasi yang merupakan salah satu risiko yang dihadapi perusahaan ketika menjalankan operasinya Joni \& Lina (2010) dalam Mufidah et al., (2018). Apabila variabilitas pendapatan tinggi, maka risiko bisnis perusahaan akan tinggi sehingga laba yang dihasilkan cenderung berfluktuasi yang berarti 
pendapatan tidak stabil, dengan adanya risiko bisnis yang tinggi perusahaan cenderung tidak mengurangi utang, tetapi tetap menggunakan utang dalam memenuhi kebutuhan dananya (Sawitri \& Lestari, 2015).

Dalam penelitian yang dilakukan oleh Wiagustini \& Pertamawati (2015) menyatakan bahwa dengan meningkatnya risiko bisnis dalam suatu perusahaan, maka penggunaan hutang jangka panjang perusahaan juga akan ikut meningkat. Hasil penelitian dari Mufidah et al., (2018) menunjukkan bahwa risiko bisnis berpengaruh tidak signifikan terhadap struktur modal. Hasil penelitian dari Kurniasari (2018) menunjukkan risiko bisnis berpengaruh tidak signifikan terhadap struktur modal perusahaan. Penelitian dari Ratri (2017) menunjukkan risiko bisnis berpengaruh negatif tidak signifikan terhadap struktur modal. Berdasarkan teori dan hasil penelitian terdahulu, maka dapat dirumuskan hipotesis sebagai berikut.

$\mathrm{H}_{1}$ : Risiko bisnis berpengaruh negatif signifikan terhadap struktur modal pada

Pada Perusahaan Makanan Dan Minuman Yang Terdaftar di BEI Tahun 2015-2019.

Perusahaan yang memiliki tingkat profitabilitas yang tinggi lebih menyukai pendanaan secara internal terlebih dahulu. Jadi, jika profitabiiitas dari suatu perusahaan mengalami peningkatan, maka struktur modal perusahaan akan mengalami penurunan seiring berkurangnya penggunaan hutang oleh perusahaan. Penelitian dari Deviani \& Sudjarni (2018) menunjukkan profitabilitas memiliki pengaruh negatif tidak signifikan terhadap struktur modal. Penelitian dari Fahruroji (2018) menunjukkan profitabilitas berpengaruh negatif tidak signifikan terhadap struktur modal. Penelitian dari Ratri (2017) menunjukkan bahwa pertumbuhan profitabilitas berpengaruh negatif tidak signifikan terhadap struktur modal. Berdasarkan teori dan hasil penelitian terdahulu, maka dapat dirumuskan hipotesis sebagai berikut.

$\mathrm{H}_{2}$ : Profitabilitas berpengaruhnegatif signifikan terhadap struktur modal Pada Perusahaan Makanan Dan Minuman Yang Terdaftar di BEI Tahun 20152019.

Struktur aktiva dapat digunakan untuk menentukan seberapa besar utang yang dapat diambil dan hal ini akan terpengaruh terhadap penentuan besarnya struktur modal. Semakin tinggi struktur aktiva (semakin besar jumlah aktiva tetap), maka struktur modal juga akan tinggi. Dengan demikian, dapat disimpulkan bahwa struktur aktiva berpengaruh terhadap struktur modal dengan didasarkan pada kenyataan bahwa semakin besar struktur aktiva, terdapat kecenderungan untuk menggunakan jumlah pinjaman yang lebih besar. Penelitian dari Maulina et al., (2018) menunjukkan struktur aktiva secara parsial berpengaruh positif signifikan terhadap struktur modal. Penelitian dari Fahruroji (2018) menunjukkan struktur aktiva berpengaruh dan positif signifikan terhadap struktur modal. Berdasarkan teori dan hasil penelitian terdahulu, maka dapat dirumuskan hipotesis sebagai berikut.

$\mathrm{H}_{3}$ : Struktur aktiva berpengaruh positif signifikan terhadap struktur modal pada Perusahaan Makanan Dan Minuman Yang Terdaftar di BEI Tahun 2015-2019. 


\section{METODE PENELITIAN}

Lokasi Penelitian ini dilakukan pada perusahaan manufaktur yang terdaftar di Bursa Efek Indonesia (BEI). Objekyang menjadi kajian dalam penelitian ini adalah Risiko Bisnis, Profitabilitas Dan Struktur Aktiva Sebagai Faktor Penentu Struktur Modal Pada Perusahaan Makanan Dan Minumanyang diproksikan melalui rasiorasio keuangan perusahan sektor makanan dan minuman yang terdaftar di Bursa Efek Indonesia periode 2015-2019. Populasi dalam penelitian ini adalah perusahaan sektor makanan dan minuman yang terdaftar di Bursa Efek Indonesia yang berjumlah dapat dijelaskan bahwa perusahaan sektor makanan dan minuman yang terdaftar di Bursa Efek Indonesia tahun 2015 sampai tahun 2019 sebanyak 14 perusahaan. Sampel pada penelitian ini adalah Perusahaan sektor makanan dan minuman di Bursa Efek Indonesia (BEI) pada periode 2015-2019 sebanyak 14 perusahaan, 1 Perusahaan mengalami kerugian pada periode pengamatan, dan Perusahaan yang menyediakan laporan keuangan dalam bentuk mata uang asing, jadi jumlah sampel menjadi 12 perusahaan, dengan jumlah pengamatan 60, dengan menggunakan metodepurposive sampling.

Data yang diperlukan dalam penelitian adalah data sekunderdengan metode dokumentasi. Dokumentasi, yaitu mengumpulkan laporan keuangan dari perusahaan sektor makanan dan minuman di Bursa Efek Indonesia dari tahun 2015-2019. Penelitian ini menggunakan dua jenis variabel yaitu variabel independen dan variabel dependen. Variabel independen penelitian ini adalah risiko binis $\left(X_{1}\right)$, profitabilitas $\left(X_{2}\right)$ dan struktur aktiva $\left(X_{3}\right)$. Variabel dependent dalam penelitian ini adalah struktur modal (Y). Struktur modal merupakan perbandingan antara utang dan modal sendiri. Struktur modal diproksikan dengan DER (Debt Equity Ratio). Rumusnya sebagai berikut (Fahmi, 2016).

\section{Total Liabilities}

Debt to equity ratio $=$

Total Shareholders Equity

Keterangan :

Total Liabilities = Total Hutang

Total shareholders' Equity = Total Modal Sendiri

Risiko bisnis dalam penelitian ini untuk mencari risiko bisinis dengan rumus (Atmaja, 2012:225).

$$
\text { EBIT }
$$

BRISK =

Total Assets

Keterangan :

EBIT = Laba Sebelum Bunga dan Pajak

Total Assets $\quad=$ Total Aktiva

Mengukur tingkat profitabilitas perusahaan dengan cara yang mengukur tingkat profitabilitas adalah Return on Assets (ROA). ROA adalah perbandingan laba bersih dengan total aktiva (assets) periode yang sama (Kasmir, 2017). Rumusnya sebagai berikut (Fahmi, 2016). 
Net Income

$R O A=$

Total Asset

Keterangan :

Net Income = Laba Bersih Setelah Pajak

Total Asset = Total Aktiva

Struktur aktiva merupakan perbandingan antara aktiva tetap dengan total aktiva yang dimiliki oleh perusahaan. Pada penelitian ini, struktur aktiva diproksikan dengan FAT (fixed assets turnover).

Penjualan (Sales)

Fixed Assets Turnover $=$

Keterangan:

Fixed Assets

Fixed Assets $=$ Total Aktiva Tetap

\section{HASIL DAN PEMBAHASAN}

Untuk lebih mengetahui bagaimana kondisi risiko bisnis, profitabilitas, struktur aktiva dan struktur modal pada Perusahaan Makanan Dan Minuman Yang Terdaftar di BEI Tahun 2015-2019, berikut ini disajikan deskripsi dari masingmasing variabel.

Tabel 1. Seleksi Sampel

\begin{tabular}{|c|c|c|}
\hline No & Kriteria Perusahaan & Jumlah \\
\hline 1 & $\begin{array}{l}\text { Perusahaan sektor makanan dan minuman di Bursa Efek Indonesia } \\
\text { (BEI) pada periode 2015-2019 }\end{array}$ & 14 \\
\hline 2 & Perusahaan mengalami kerugian pada periode pengamatan & (1) \\
\hline \multirow[t]{3}{*}{3} & $\begin{array}{l}\text { Perusahaan yang menyediakan la poran keuangan dalam bentuk mata } \\
\text { uang asing }\end{array}$ & (1) \\
\hline & Jumlah sampel & 12 \\
\hline & Jumlah pengamatan $5 \times 12$ bulan & 60 \\
\hline
\end{tabular}

Sumber: Data Penelitian, 2020

Berdasarkan proses seleksi sampel pada Tabel 1, diperoleh 12 perusahaan sehingga total sampel yang diambil selama 5 tahun adalah sebanyak 60 pengamatan.

Tabel 2. Hasil Uji Statistik Deskriptif

\begin{tabular}{lccccc}
\hline & $\mathrm{N}$ & Minimum & Maximum & Mean & Std. Deviation \\
\hline X1 & 60 & 0,02 & 0,75 & 0,300 & 0,222 \\
X2 & 60 & 4,08 & 7,57 & 5,722 & 1,099 \\
X3 & 60 & 0,01 & 4,54 & 1,918 & 1,346 \\
Y & 60 & 1,01 & 3,56 & 1,734 & 0,740 \\
Valid N (listwise) & 60 & & & & \\
\hline
\end{tabular}

Sumber: Data Penelitian, 2020

Pada Tabel 2, dapat diketahui nilai terendah, nilai tertinggi, mean, dan standar deviasi dari masing-masing variabel. Masing-masing variabel akan dijelaskan sebagai berikut. Risiko Bisnis $\left(X_{1}\right)$, Tabel 2, menunjukkan variabel risiko Bisnis $\left(X_{1}\right)$ memiliki nilai terendah 0,02 dan nilai tertinggi 0,75 . Nilai rata-rata dari 
variabel risiko bisnis $\left(\mathrm{X}_{1}\right)$ adalah 0,300 dan standar deviasi dari variabel risiko bisnis $\left(X_{1}\right)$ adalah sebesar 0,222. Hal ini berarti standar deviasi lebih kecil dari mean menunjukkan sebaran variabel data tidak ada kesenjangan yang cukup besar dari data risiko bisnis terendah dan tertinggi.

Profitabilitas $\left(\mathrm{X}_{2}\right)$, Tabel 2, menunjukkan bahwa variabel profitabilitas $\left(\mathrm{X}_{2}\right)$ memiliki nilai terendah 4,08 dan nilai tertinggi 7,57. Nilai rata-rata dari variabel profotabilitas $\left(\mathrm{X}_{2}\right)$ adalah 5,7227dan standar deviasi dari variabel profttabilitas $\left(\mathrm{X}_{2}\right)$ adalah sebesar 1,099. Hal ini berarti standar deviasi lebih kecil dari mean menunjukkan sebaran variabel data tidak ada kesenjangan yang cukup besar dari data profitabilitasterendah dan tertinggi.

Struktur Aktiva $\left(X_{3}\right)$, Tabel 2, menunjukkan bahwa variabel struktur aktiva $\left(X_{3}\right)$ memiliki nilai terendah 0,01 dan nilai tertinggi 4,54 . Nilai rata-rata dari variabel struktur aktiva $\left(X_{3}\right)$ adalah 1,918 dan standar deviasi dari variabel struktur aktiva $\left(X_{3}\right)$ adalah sebesar 1,346. Hal ini berarti standar deviasi yang lebih kecil dari mean menunjukkan sebaran variabel data tidak ada kesenjangan yang cukup besar dari data struktur aktiva terendah dan tertinggi.

Struktur Modal (Y), Tabel 2, menunjukkan bahwa variabel struktur modal (Y) memiliki nilai terendah 1,01 dannilai tertinggi3,56. Nilai rata-rata dari variabel struktur modal (Y) adalah 1,734 dan standar deviasi dari variabel struktur modal (Y) adalah sebesar 0,740, Hal ini berarti standar deviasi yang lebih kecil dari mean menunjukkan sebaran variabel data tidak ada kesenjangan yang cukup besar dari data struktur modalterendah dan tertinggi.

Tabel 3. Hasil Uji Normalitas

\begin{tabular}{llc}
\hline & & Unstandardized Residual \\
\hline $\mathrm{N}$ & Mean & 60 \\
Normal Parametersa, & Std. Deviation & 0,000 \\
& Absolute & 0,347 \\
Most Extreme Differences & Positive & 0,276 \\
& Negative & 0,276 \\
Test Statistic & & $-0,076$ \\
Asymp.Sig.(2-tailed) & & 0,076 \\
\hline
\end{tabular}

Sumber: Data Penelitian, 2020

Berdasarkan Tabel 3, dapat diketahui bahwa nilai Asymp. Sig. (2-tailed) sebesar 0,072, dimana lebih besar 0,05. Hal ini berarti seluruh data berdistribusi normal.

Tabel 4. Hasil Uji Multikolinearitas

\begin{tabular}{llcc}
\hline \multirow{2}{*}{ Model } & & \multicolumn{2}{c}{ Collinearity Statistics } \\
\cline { 3 - 4 } & & Tolerance & VIF \\
\hline \multirow{2}{*}{1} & X1 & 0,796 & 5,695 \\
& X2 & 0,492 & 3,192 \\
& X3 & 0,486 & 2,583 \\
\hline
\end{tabular}

Sumber: Data Penelitian, 2020

Berdasarkan Tabel 4, menunjukkan bahwa nilai tolerance untuk ketiga variabel bebas lebih besar dari 0,1 dan nilai VIF lebih kecil dari 10, Sehingga tidak terdapat korelasi diantara variabel bebas dalam model regresi linear berganda tersebut atau model regresi linier berganda bebas dari multikolinearitas. 
Tabel 5. Hasil Uji Autokorelasi

\begin{tabular}{ccc}
\hline Model & Durbin-Watson & Du \\
\hline 1 & 1,998 & 1,55 \\
\hline Sumber:
\end{tabular}

Sumber: Data Penelitian, 2020

Berdasarkan hasil perhitungan uji autokorelasi menggunakan Uji DurbinWatson (DW-test) pada Tabel 5, diperoleh nilai sebesar 1,998, dimana nilai du = $1,55, \mathrm{k}$ (jumlah varaibel bebas) $=3, \mathrm{n}=60$, dengan perhitungan sebagai berikut : $\mathrm{du}<\mathrm{dw}<4-\mathrm{du} 1,55<1,998<4-1,551,55<1,998<2,45$. Berdasarkan hal tersebut dapat disimpulkan bahwa tidak adanya autokorelasi pada penelitian ini, yang ditunjukkan dari nilai 1,55 <1,998 <2,45.

Tabel 6. Hasil Uji Heteroskedastisitas

\begin{tabular}{llccccc}
\hline \multirow{2}{*}{ Model } & \multicolumn{2}{c}{ Unstandardized Coefficients } & $\begin{array}{c}\text { Standardized } \\
\text { Coefficients }\end{array}$ & $\mathrm{t}$ & Sig. \\
\cline { 2 - 7 } & (Constant) & 0,200 & Std. Error & Beta & & \\
\hline 1 & $-0,001$ & 0,092 & & 2,171 & 0,034 \\
& X1 & 0,062 & $-0,002$ & $-0,017$ & 0,987 \\
& X2 & 0,033 & 0,020 & 0,351 & 1,652 & 0,104 \\
& X3 & $-0,031$ & 0,016 & $-0,408$ & $-1,941$ & 0,057 \\
\hline
\end{tabular}

Sumber: Data Penelitian, 2020

Berdasarkan hasil uji heteroskedastisitas dapat diketahui nilai signifikan variabel-variabel bebas lebih besar dari pada 0,05 sehingga model bebas dari heteroskedastisitas.

Tabel 7. Hasil Uji Regresi Linier Berganda

\begin{tabular}{|c|c|c|c|c|c|c|}
\hline & \multirow[t]{2}{*}{ Model } & \multicolumn{2}{|c|}{$\begin{array}{c}\text { Unstandardized } \\
\text { Coefficients }\end{array}$} & \multirow{2}{*}{$\begin{array}{c}\text { Standardized } \\
\text { Coefficients } \\
\text { Beta } \\
\end{array}$} & \multirow[t]{2}{*}{$t$} & \multirow[t]{2}{*}{ Sig. } \\
\hline & & B & Std. Error & & & \\
\hline \multirow[t]{4}{*}{1} & (Constant) & 2,184 & 0,318 & & 6,864 & 0,000 \\
\hline & X1 & 688 & 0,215 & 0,207 & 3,200 & 0,002 \\
\hline & $\mathrm{X} 2$ &,- 329 & 0,069 & $-0,488$ & $-4,735$ & 0,000 \\
\hline & X3 & 639 & 0,056 & 1,162 & 11,403 & 0,000 \\
\hline \multicolumn{2}{|c|}{ Adjusted $\mathrm{R}^{2}$} & 0,768 & & & & \\
\hline \multicolumn{2}{|c|}{ Uji F } & 66,078 & & & & \\
\hline \multicolumn{2}{|c|}{ Sig F } & 0,000 & & & & \\
\hline
\end{tabular}

Sumber: diolah (2020)

Berdasarkan nilai-nilai pada Tabel 7, tersebut, dapat dibuat suatu persamaan model regresi linear berganda pengaruh profitabilitas, leverage, ukuran perusahaan, dan terhadap nilai perusahaan adalah sebagai berikut.

$Y=2,184+0,688 X_{1}-0,329 X_{2}+0,639 X_{3}$

Berdasakan persamaan model analisis regresi linier berganda tersebut dapat diinterpretasikan bahwa nilai koefisien regresi sebesar 0,688 memiliki arti jika nilai risiko bisnis $\left(\mathrm{X}_{1}\right)$ mengalami peningkatan maka struktur modal $(\mathrm{Y})$ meningkat naik sebesar 0,688 satuan, dengan asumsi variabel lain tetap konstan. Nilai koefisien regresi sebesar -0,329 memiliki arti jika profitabilitas meningkat $\left(\mathrm{X}_{2}\right)$ maka struktur modal mengalami penurunan, dengan asumsi variabel lain tetap konstan. Nilai koefisien regresi sebesar 0,639 memiliki arti jika struktur aktiva meningkat $\left(\mathrm{X}_{3}\right)$, maka struktur modal $(\mathrm{Y})$ mengalami peningkatan, dengan asumsi variabel lain tetap konstan. 
Hipotesis pertama $\left(\mathrm{H}_{1}\right)$ menyatakan bahwa risiko bisnis berpengaruh positif dan signifikan terhadap struktur modal pada Perusahaan Makanan Dan Minuman Yang Terdaftar di BEI Tahun 2015-2019. Berdasarkan hasil pada Tabel 7, nilai siginifikasnsi yang dihasilkan 0,002 lebih kecil dari 0,005 sehinggahipotesis H1 yang menyatakan bahwa risiko bisnis berpengaruh positif dan signifikan terhadap struktur modal pada Perusahaan Makanan Dan Minuman Yang Terdaftar di BEI Tahun 2015-2019 diterima. Hasil temuan ini membuktikan pecking order theory. Myers dan Majluf (1984) menyatakan bahwa pecking order theory merupakan teori struktur modal yang dapat menjelaskan bahwa manajer mempertimbangkan masalah keamanan dalam memilih pendanaan yaitu kecenderungan perusahaan mengandalkan sumber dana internal.

Hasil penelitian ini sesuai dengan pernyataan dari Joni \& Lina (2010) dalam Mufidah et al., (2018) bahwa ketidakmampuan suatu perusahaan dalam memenuhi kebutuhan dananya untuk kegiatan operasi yang merupakan salah satu risiko yang dihadapi perusahaan ketika menjalankan operasinya.Hasil ini sesuai dengan penelitian yang dilaksanakan oleh Mufidah et al., (2018) menunjukkan bahwa risiko bisnis berpengaruh positif tidak signifikan terhadap struktur modal. Hasil penelitian dari Kurniasari (2018) menunjukkan risiko bisnis berpengaruh positif tidak signifikan terhadap struktur modal perusahaan. Hal ini berarti meningkatnya risiko bisnis dalam suatu perusahaan, maka penggunaan hutang jangka panjang perusahaan juga akan ikut meningkat.

Hipotesis kedua $\left(\mathrm{H}_{2}\right)$ menyatakan bahwa profitabilitas berpengaruh negatif dan signifikan terhadap struktur modal pada Perusahaan Makanan Dan Minuman Yang Terdaftar di BEI Tahun 2015-2019. Berdasarkan hasil pada Tabel 7 , nilai siginifikasnsi yang dihasilkan 0,000 lebih kecil dari 0,005 sehingga hipotesis $\mathrm{H} 2$ yang menyatakan bahwa profiabilitas berpengaruh negatif dan signifikan terhadap struktur modal pada Perusahaan Makanan Dan Minuman Yang Terdaftar di BEI Tahun 2015-2019diterima. Hasil temuan ini membuktikan pecking order theory, yaitu perusahaan yang memiliki tingkat keuntungan yang besar cenderung memiliki hutang yang kecil. Perusahaan yang memiliki profitabilitas yang tinggi akan mendanai kegiatan operasionalnya menggunakan sumber pendanaan internal daripada sumber pendanaan eksternal. Hal ini berarti jika profitabilitas dari suatu perusahaan mengalami peningkatan, maka struktur modal perusahaan akan mengalami penurunan seiring berkurangnya penggunaan hutang oleh perusahaan.

Hasil penelitian ini sesuai dengan pernyataan dari Martono \& Harjito (2007) dalam Ratri (2017) bahwa profitabilitas adalah kemampuan perusahaan untuk memperoleh laba dari modal yang digunakan untuk menghasilkan laba.Hasil penelitian ini sesuai dengan penelitian dari Deviani \& Sudjarni (2018) menunjukkan profitabilitas memiliki pengaruh negatif tidak signifikan terhdap struktur modal. Penelitian dari Fahruroji (2018) menunjukkan profitabilitas berpengaruh dan negatif dan signifikan terhadap struktur modal. Penelitian dari Ratri (2017) menunjukkan bahwa pertumbuhan profitabilitas berpengaruh negatif dan signifikan terhadap struktur modal.

Hipotesis ketiga $\left(\mathrm{H}_{3}\right)$ menyatakan bahwa struktur aktiva berpengaruh positif signifikan terhadap struktur modal pada Perusahaan Makanan Dan Minuman Yang Terdaftar di BEI Tahun 2015-2019. Berdasarkan hasil pada Tabel 
7 , nilai siginifikasnsi yang dihasilkan 0,000 lebih kecil dari 0,005 sehingga hipotesis H3 yang menyatakan bahwa struktur aktiva berpengaruh positif signifikan terhadap struktur modal pada Perusahaan Makanan Dan Minuman Yang Terdaftar di BEITahun 2015-2019 diterima. Hasil temuan ini membuktikan Pecking Order Theory, yaitu perusahaan cenderung lebih menyukai sumber pendanaan internal daripada penggunaan sumber pendanaan eksternal. membutuhkan jaminan yang setimpal dengan jumlah yang dipinjamkan pada perusahaan. Hal ini berarti struktur aktiva berpengaruh terhadap struktur modal dengan didasarkan pada kenyataan bahwa semakin besar struktur aktiva, terdapat kecenderungan untuk menggunakan jumlah pinjaman yang lebih besar.

Hasil penelitian ini sesuai dengan pernyataan dari Brigham \& Houston (2011) yang menyatakan bahwa perusahaan yang memiliki aset tetap dalam jumlah besar dapat menggunakan utang dalam jumlah besar, karena aset tersebut dapat digunakan sebagai jaminan atas pinjaman perusahaan. Hasil penelitian ini sesuai dengan penelitian dari Maulina et al., (2018) menunjukkan struktur aktiva secara parsial berpengaruh positif signifikan terhadap struktur modal. Penelitian dari Fahruroji (2018) menunjukkan struktur aktiva berpengaruh dan positif signifikan terhadap struktur modal.

\section{SIMPULAN}

Berdasarkan hasil penelitian dan pembahasan yang telah dikemukakan sebelumnya, maka kesimpulan penelitian ini adalah sebagai berikut, Risiko bisnis berpengaruh positif signifikan terhadap struktur modal pada Perusahaan Makanan Dan Minuman Yang Terdaftar di BEI Tahun 2015-2019. Profiabilitas berpengaruh negatif signifikan terhadap struktur modal pada Perusahaan Makanan Dan Minuman Yang Terdaftar di BEI Tahun 2015-2019. Struktur aktiva berpengaruh positif signifikan terhadap struktur modal pada Perusahaan Makanan Dan Minuman Yang Terdaftar di BEI Tahun 2015-2019.

Berdasarkan hasil dan pembahasan penelitian yang telah disampaikan, maka saran yang dapat diberikan kepada pihak perusahaan, investor serta penelitian selanjutnya sebagai berikut. Bagi calon investor, sebaiknya lebih selektif lagi dalam memilih perusahaan yang akan dijadikan tempat berinvestasi. Salah satu pertimbangan yang bisa diambil dari penelitian ini yaitu memperhatikan risiko bisnis (BRISK), profitabilitas (ROA) struktur aktiva (FAT) dan perusahaan karena berpengaruh terhadap pengoptimalan struktur modal. Untuk penelitian selanjutnya sebaiknya untuk menggunakan kombinasi variabel lain diluar variabel struktur aktiva (FAT), profitabilitas (ROA) dan juga risiko bisnis (BRISK), penggunaan perusahaan pada sektor lainnya maupunkombinasi sektor lainnya, sehingga akan memberikan hasil yang dapat dibandingkanmaupun generalisasi perusahaan yang terdaftar di Bursa Efek Indonesia, dan penelitian selanjutnya juga diharapkan dapat melakukan penelitian dengan menggunakan data time series yang up to date/terbaru, sehingga hasilnya juga akan semakin akurat.

\section{REFERENSI}

Alipour, M., Mohammadi, M.F.S. and Derakhshan, H. (2015). Determinants of capital structure: An empirical study of firms in Iran. International Joumal 
of Law and Management, 57(1), 53-83. https:/ / doi.org/10,1108/ IJLMA-012013-0004

Ananto, M. (2015). Pengaruh Profitabilitas, Kepemilikan Institusional, Growth Opportunity Dan Likuiditas Terhadap Struktur Modal Pada Perusahaan Manufaktur Yang Terdaftar Di Bursa Efek Indonesia. Jurusan Manajemen Universitas Negeri Yogyakarta. 1-27.

Arabella, H. (2018). Pengaruh Risiko Bisnis, Struktur Aktiva, Pertumbuhan Penjualan Dan Profitabilitas Terhadap Struktur Modal Pada Perusahaan Manufaktur Sektor Industri Dasar Dan Kimia Yang Terdaftar Di Bursa Efek Indonesia. Universitas Islam Indonesia.

Ariandani, P. S. dan Yadnyana, I. K. (2016). Likuiditas Memoderasi Pengaruh Profitabiltas Dan Investment Opportunity Set (Ios) Pada Kebijakan Dividen. E-Jurnal Akuntansi, 17(1), 615-634.

Atmaja, L. S. (2012). Teori dan Praktik Manajemen Keuangan. Yogyakarta:ANDI. Bhawa, I. B. M. D. dan Dewi, M. R. (2015). Pengaruh Ukuran Perusahaan, Likuiditas, Profitabilitas, Dan Risiko Bisnis Terhadap Struktur Modal Perusahaan Farmasi. E-Jurnal Manajemen Universitas Udayana, 4(7), 19491966.

Brigham, E. F. dan Houston, J. F. (2011). Dasar-dasar Manajemen Keuangan (Essential of Financial Management). Edisi Ke Sebelas, buku 1. Terjemahan oleh Ali Akbar Yulianto. Jakarta: Salemba Empat.

Deviani, M. Y. dan Sudjarni, L. K. (2018). Pengaruh Tingkat Pertumbuhan, Struktur Aktiva, Profitabilitas, Dan Likuiditas Terhadap Struktur Modal Perusahaan Pertambangan Di BEI. 7(3), 1222-1254.

Fahmi, I. (2016). Pengantar Manajemen Keuangan Teori dan Soal Jawab. Bandung: ALFABETA.

Fahruroji, M. dan Iwan. (2018). Analisis Profitabilitas, Ukuran, Pertumbuhan Dan Aktiva Terhadap Struktur Modal Pada Perusahaan Manufaktur Di BEI. Fakultas Ekonomi Universitas Gunadarma Jakarta, XVIII(1), 107-116.

Gitman, L. J. dan Chad, J. Z. (2009). Principle, of Managerial Finance., $13^{\text {th }}$ Edition. Global Edition: Person Education Limited.

Jensen, M. C. dan Meckling, W. H. (1976). Theory Of The Firm: Managerial Behavior, Agency Costs And Ownership Structure. Journal Of Financial Economics 3, 305-360,

Joni dan Lina. (2010). Faktor-Faktor Yang Mempengaruhi Struktur Modal. STIE Trisakti, 12(2), 82-97. https://doi.org/10,34208/jba.v12i2.187

Juliantika, N. L. A. A. M. dan Dewi, M. R. (2016). Pengaruh Profitabilitas, Ukuran Perusahaan, Likuiditas, Dan Risiko Bisnis TerhadapStruktur Modal Pada Perusahaan Property Dan Realestate. E-Jurnal Manajemen Universitas Udayana, 5(7), 4161-4192.

Kasmir. (2017). Bank dan Lembaga Keuangan Lainnya. Edisi Keenam. Jakarta: PT. Raja Grafindo Persada

Khairin, M. Y. dan Harto, P. (2014). Pengaruh Growth Opportunity, Profitabilitas, Fixed Asset Ratio Dan Risiko Pasar Terhadap Struktur Modal. Diponegoro Journal of Accounting, 3(2), 1-12. 
Kurniasari, M. (2018). Pengaruh Profitabilitas, Risiko Bisnis, Struktur Aktiva, Ukuran Perusahaan Dan Likuiditas Terhadap Struktur Modal Perusahaan. Fakultas Ekonomi Universitas Muhammadiyah Surakarta.

LIem, J. H., Murhadi, W. R., dan Sutejo, B. S. (2013). Faktor-Faktor Yang Mempengaruhi Struktur Modal Pada Industri Consumer Goods Yang Terdaftar Di Bei Periode 2007-2011. Jurnal Ilmiah Mahasiswa Universitas Surabaya, 2(1), 1-11.

Liestyasih, L. P. E. dan Yadnya, I. P. (2015). Pengaruh Operating Leverage, Ndts, Struktur Aktiva, Dan Growth Opportunity Terhadap Struktur Modal. EJurnal Manajemen Universitas Udayana, 4(2),607-621.

Martono dan Harjito, D. A. (2007). Manajemen Keuangan. Cetakan Keempat. Yogyakarta: EKONESIA.

Maulina, G., Nuzula, N. F., dan Nurlaily, F. (2018). Pengaruh Faktor-Faktor Penentu Struktur Modal Terhadap Struktur Modal (Studi pada Perusahaan Manufaktur yang Terdaftar di Bursa Efek Indonesia periode 2014-2016). Fakultas Ilmu Administrasi Universitas Brawijaya, 58(1), 156-165.

Mufidah, Ulupui, I. G. K. A. dan Prihatni, R. (2018). Pengaruh Profitabilitas, Likuiditas, Dan Risiko Bisnis Pada Struktur Modal Perusahaan Properti Dan Real Estate Di Bursa Efek Indonesia. Matrik : Jurnal Manajemen, Strategi Bisnis Dan Kewirausahaan, 12(2), 129138.https:/ /doi.org/10,24843/MATRIK:JMBK.2018.v12.i02.p05

Myers, S.C. and Majluf, N.S. (1984) Corporate Financing and Investment Decisions When Firms Have Information That Investors Do Not Have. Journal of Financial Economics, 13, 187-221. https:/ / doi.org/10,1016/0304-405X(84)90023-0

Pattweekkongka, S. dan Napompech, K. (2014). Determinants Of Capital Structure: Evidence From Thai Lodging Companies. King Mongkut's Institute Of Technology, Thailand, 7(4), 45-52. https:/ / doi.org/10,5430/afr.v8n4p186

Primantara, A. N. A. D. Y. dan Dewi, M. R. (2016). Pengaruh Likuiditas, Profitabilitas, Risiko Bisnis, Ukuran Perusahaan, Dan Pajak Terhadap Struktur Modal. E-Jurnal Manajemen Universitas Udayana, 5(5), 2696-2726.

Ratri, A. M. (2017). Pengaruh Size, Likuiditas. Profitabilitas, Risiko Bisnis, Dan Pertumbuhan Penjualan Terhadap Struktur Modal pada Sektor Industri Properti. JRMB, 12(1), 13-24.

Riyanto, B. (2011). Dasar-Dasar Pembelanjaan Perusahaan. Edisi 4, Cetakan Ketujuh. Yogyakarta: BPFE UGM.

Rodoni, A. dan Ali, H. (2014). Manajemen Keuangan. Jakarta: Mitra Wacana Media.

Sawitri, N. P. Y. R. dan Lestari, P. V. (2015). Pengaruh Risiko Bisnis, Ukuran Perusahaan Dan Pertumbuhan Penjualan Terhadap Struktur Modal. EJurnal Manajemen Universitas Udayana, 4(5), 1238-1251.

Setyawan, A. I. W., Topowijono, dan Nuzula, N. F. (2016). Pengaruh firm size, growth opportunity, profitability, Business Risk, Effective Tax Rate, Asset Tangibility, Firm Age Dan Liquidity Terhadap Struktur Modal Perusahaan (studi pada perusahaan sektor property dan real estate yang terdaftar di BEI tahun 2009-2014. Jurnal Administrasi dan Bisnis, 31(1), 108-117. 
Sheikh, N. A. dan Wang, Z. (2011). Determinants of capital structure: An empirical study of firms in manufacturing industry of Pakistan. Managerial Finance, 37(2), 117-133. https:// doi.org/10,1108/03074351111103668

Spence, M. (1973). Job Market Signaling. Geburtshilfe und Frauenheilkunde, 87(3), 355-374. https:/ / doi.org/10,1055/s-2004-820924

Suweta, N. M. N. P. D. dan Dewi, M. R. (2016). Pengaruh Pertumbuhan Penjualan, Struktur Aktiva, Dan Pertumbuhan Aktiva Terhadap Struktur Modal. EJurnal Manajemen Universitas Udayana, 5(8), 5172-5199.

Wiagustini, N. L. P. dan Pertamawati, N. P. (2015). Pengaruh Risiko Bisnis dan Ukuran Perusahaan pada Struktur Modal dan Nilai perusahaan pada Perusahaan Farmasi di Bursa Efek Indonesia. Matrik: Jurnal Manajemen, Strategi Bisnis dan Kewirausahaan, 9(2), 112-122. 